\title{
QUANTIFICATION OF NATURAL POPULATIONS OF Gluconacetobacter diazotrophicus AND Herbaspirillum spp. IN SUGAR CANE (Saccharum spp.) USING DIFFERENT POLYCLONAL ANTIBODIES
}

\author{
Silva-Froufe, Lúcia Gracinda da $^{1}$; Boddey, Robert Michael ${ }^{2}$; Reis, Veronica Massena ${ }^{2}$ * \\ ${ }^{1}$ Departamento de Bioquímica e Biologia Molecular, Setor de Ciências Biológicas, Centro Politécnico, Universidade Federal \\ do Paraná, Curitiba, PR, Brasil; ${ }^{2}$ Embrapa Agrobiologia, Seropédica, RJ, Brasil.
}

Submitted: August 22, 2008; Returned to authors for corrections: March 21, 2009; Approved: May 15, 2009.

\begin{abstract}
The species Gluconacetobacter diazotrophicus, Herbaspirillum seropedicae and H. rubrisubalbicans are endophytic $\mathrm{N}_{2}$-fixing [diazotrophic] bacteria which colonise not only roots, but also the aerial tissue of sugar cane. However, the technique most commonly used to quantify the populations of these microbes in plants is by culturing serial dilutions of macerates of plant tissues in $\mathrm{N}$ free semi-solid media which are only semi-selective for the species/genera [the Most Probable Number (MPN) Technique] and each culture must be further subjected to several tests to identify the isolates at the species level. The use of species-specific polyclonal antibodies with the indirect ELISA (enzyme-linked immunosorbent assay) can be an alternative which is rapid and specific to quantify these populations of bacteria. This study was performed to investigate the viability of adapting the indirect ELISA technique to quantify individually the populations of these three species of diazotroph within the root and shoot tissues of sugarcane. The results showed that species-specific polyclonal antibodies could be obtained by purifying sera in protein-A columns which removed non-specific immuno-globulins. It was possible to quantify the three bacterial species in the Brazilian sugarcane variety SP 70-1143 in numbers above $10^{5}$ cells per $\mathrm{g}$ fresh weight in roots, rhizomes and leaves. The numbers of the different bacterial species evaluated using the ELISA technique were found to be higher than when the same populations were evaluated using the MPN technique, reaching 1400 times greater for G. diazotrophicus and 225 times greater for Herbaspirillum spp. These results constitute the first quantification of Herbaspirillum using immunological techniques.
\end{abstract}

Key words: diazotrophic bacteria, ELISA, immunoquantification

\section{INTRODUCTION}

The specie Gluconacetobacter diazotrophicus (43, 44) [formally Acetobacter diazotrophicus (13)] and two species of Herbaspirillum: H. seropedicae and H. rubrisubalbicans $(3,5,6)$ have been found to colonise the rhizosphere and the internal tissues of sugar cane $(9,23,41)$. They are transmitted to the next crop by stem cuttings (setts) and are considered as

*Corresponding Author. Mailing address: Embrapa Agrobiologia, BR 465, km 7, Caixa Postal 74505, CEP 23890-000 Seropédica, RJ, Brazil.; Email: veronica@,cnpab.embrapa.br 
obligate endophytic diazotrophic bacteria, as their survival in the soil is very poor $(4,26)$. Normally, the procedure to quantify populations of these bacteria utilises semi-solid Nfree media inoculated with plant macerate after serial dilutions $(8,11,24,32,33)$. Enumeration has been achieved using the Most Probable Number (MPN) technique (28) based on positive scoring of semi-solid cultures where the characteristic pellicle formation is observed. Both the use of semi-specific media and the use of the MPN technique are fraught with difficulties and the numbers obtained almost certainly underestimate true populations size, as was indicated by the results of $\mathrm{Li}$ and MacRae (19) for Gluconacetobacter diazotrophicus.

In the utilisation of the MPN method it is assumed that the bacteria are released from adherence to the plant tissue and that no aggregates are formed so that the maceration step extracts contain all the bacteria present in the plant tissue and subsequent serial dilutions are based on a homogenous suspension of individual bacterial cells. It is further assumed that single cells of the target organisms can grow under these conditions and no other bacteria present in the suspension inhibit their growth in the semi-solid medium.

The use of Enzyme Linked Immunosorbent Assay (ELISA) was firstly used to detect viruses (18) and subsequently, amongst many other applications, has been applied to detect and count rhizobia $(27,39,42)$. There have been several applications of this technique in studies of associative $\mathrm{N}_{2}$-fixing bacteria $(7,17,19,31,34,37,38)$. The ELISA procedure has several advantages in comparison to the MPN technique. In this immunological method, the bacteria do not have to be completely dispersed into a suspension of individual cells, as is supposed to occur during the dilution procedure of MPN counts. The complete analysis takes less than $24 \mathrm{~h}$ and the result can be specific to the target bacteria if the sera are prepared in a suitable manner to achieve this objective. The extracted sample after fixation can be maintained in the refrigerator and analysed several times or the material adsorbed on the ELISA plate can be stored for a long period under the same conditions (40).
The aim of this study was to quantify the natural populations of Gluconacetobacter diazotrophicus, Herbaspirillum seropedicae and H. rubrisubalbicans present in several samples of sugar cane tissue using species-specific polyclonal antibodies for the indirect ELISA technique.

\section{MATERIALS AND METHODS}

\section{Production and tests of the polyclonal antisera}

The antibodies were obtained by immunisation of young New Zealand rabbits. All bacterial strains were obtained from the bacterial collection of Embrapa-Agrobiologia (strains identified by the prefix BR). Strains used for immunisation included the type strain of $H$. seropedicae Z67 (BR 11175, ATCC 35892, DSM 6445, LMG 6513) isolated from roots of rice in Brazil and strain HRC54 (BR 11335) isolated from roots of sugar cane in Brazil. For H. rubrisubalbicans, type strain M4 (BR 11192, ATCC 19308, DSM 9440, LMG 2286) isolated from sugar cane in the USA was used, along with HCC103 (BR 11504) isolated from roots of sugar cane in Brazil. For Gluconacetobacter diazotrophicus the type strain PR2 (BR 11200, ATCC 49039, LMG 8067) and strain PAL 3 (BR 11280, LMG 8066) were used, both isolated from roots of sugar cane in Brazil.

Pure colonies of Gluconacetobacter diazotrophicus were grown in $50 \mathrm{~mL}$ of SYP medium containing in $\mathrm{g} \mathrm{L}^{-1}$ : sucrose, 10; yeast extract, 3; $\mathrm{K}_{2} \mathrm{HPO}_{4}, 1 ; \mathrm{KH}_{2} \mathrm{PO}_{4}$, 3; final $\mathrm{pH} 6.2$ (10). Herbaspirillum spp. were grown on Nutrient Broth [beef extract $\left(3 \mathrm{~g} \mathrm{~L}^{-1}\right)$ and peptone $\left(5 \mathrm{~g} \mathrm{~L}^{-1}\right)$ with glycerol $\left(10 \mathrm{~g} \mathrm{~L}^{-}\right.$ $\left.{ }^{1}\right)$ ] (23) for $24 \mathrm{~h}$ at $30^{\circ} \mathrm{C}$ agitated on a rotary shaker at a 140 rpm. Pure cells of both G. diazotrophicus and Herbaspirillum spp. were washed five times in sterile water $(2,000 \times \mathrm{g}$ for 10 min) and suspended in phosphate saline buffer (PBS, pH 7.2, $50 \mathrm{mM}$ ). The inoculum containing $\sim 10^{9} \mathrm{cfu} \mathrm{mL}^{-1}$ were treated for $30 \mathrm{~min}$ at $90^{\circ} \mathrm{C}$ in a water bath to eliminate the proteins of the flagella (29). The first immunisation was performed subcutaneously (200 $\mu \mathrm{L}$ per injection) using $1.0 \mathrm{~mL}$ of fresh bacterial cells mixed with $0.5 \mathrm{~mL}$ of incomplete Freund's adjuvant and $0.5 \mathrm{~mL}$ of complete adjuvant, introduced at 
eight or ten different locations of the rabbit's body. Samples of rabbit blood were taken before the first injection to be used as pre-immune sera. Once a week, during 8 weeks, the immunisation was repeated intramuscularly using $1 \mathrm{~mL}$ of bacterial cells without adjuvant. After this period, the rabbits were bled $(\sim 30 \mathrm{~mL})$ and the sera were obtained after standing overnight. The sera were centrifuged to eliminate the red blood cells and heated at $56{ }^{\circ} \mathrm{C}$ for $1 \mathrm{~h}$ in a water bath. The sera were stored frozen at $-20{ }^{\circ} \mathrm{C}$ in $15 \mathrm{~mL}$ glass tubes.

The obtained antisera were purified using a protein-A column (ABICAP, Merck, Germany) to extract the IgG fraction. The buffer used to desorb the IgG fraction from the column was modified to achieve the highest amount of the specific immunoglobulins. Glycine buffer $(100 \mathrm{mM})$ at $\mathrm{pH}$
4.0 was used for $\operatorname{IgG} 2 \mathrm{a}$ and $\operatorname{IgG} 2 \mathrm{~b}$ and at $\mathrm{pH} 3.0$ for $\operatorname{IgG} 1$ and $\mathrm{IgG}$. After purification, the antibodies were neutralised using $\mathrm{NaOH}(0.5 \mathrm{M})$ to achieve $\mathrm{pH}$ 7.0. The protein concentration was measured at $280 \mathrm{~nm}$ (14), where one unit of absorbance was found to represent $0.75 \mathrm{mg}$ of protein.

The important characteristics of the polyclonal antibodies used are listed in Table 1. The localization of the antigenic determinants was performed as described by Bachhawar \& Ghosh (2) modified by Schloter et al. (37). The protein concentration was measured at $280 \mathrm{~nm}$ (14), where one unit of absorbance was found to represent $0.75 \mathrm{mg}$ of protein. The validation of these antibodies has been described previously in details including the ultra-structure of the cells colonising micropropagated sugar cane $(16,25)$.

Table 1. Properties of the polyclonal antibodies used

\begin{tabular}{lccccc}
\hline $\begin{array}{c}\text { Name of } \\
\text { antisera }\end{array}$ & Cross reactivity & $\begin{array}{c}\text { Antigenic } \\
\text { determinant }\end{array}$ & $\begin{array}{c}\text { Stability of } \\
\text { antigen }\end{array}$ & Affinity & Reference \\
\hline GD PR2 & Species-specific & 27kDA OMP & Stable & High & 16 \\
GD PAL3 & Species-specific & OMP & Stable & High & High \\
HS Z67 & Species-specific & OMP & Stable & High & 15 \\
HS HRC54 & Species-specific & OMP & Stable & High \\
HR M4 & Species-specific & OMP & Stable & High \\
HR HCC103 & Species-specific & OMP & Stable &
\end{tabular}

\section{Cross Reaction}

All immunoassays were performed with 96-well PVC microtitre plates (Costar, Cambridge, USA) using the protocol of Schloter et al. (36) with the plates incubated under agitation of the primary and secondary antibodies (300 rpm for $3 \mathrm{~min}$ ) and after addition of the substrate (100 rpm for $3 \mathrm{~min}$ ). The enzyme used for the ELISA reaction was the peroxidase-coupled anti-rabbit secondary antibody [Amersham, Braunschweig, Germany] and ABTS [2.2'- azinobis (3-ethylbenzthiazolinesulfonic acid) - Boeringer] as substrate, as used by Schloter et al. (39). To determine the titre of both antibodies, several dilutions were used before and after the purification on the protein-A column. To verify the specificity, several strains of different species of bacteria (both $\mathrm{N}_{2}$-fixing and not) were used (Tables 2, 3 and 4). Bacterial strains were inoculated in liquid Dygs media (35) of the following composition $\left(\mathrm{g} \mathrm{L}^{-1}\right)$ : glucose, 2.0; malic acid, 2.0; peptone, 1.5; yeast extract, $2.0 ; \mathrm{MgSO}_{4} 7 \mathrm{H}_{2} \mathrm{O}, 0.5$; L- 
glutamic acid, 1.5; final $\mathrm{pH}$ 6.0. Cells were grown on a rotary shaker overnight at $140 \mathrm{rpm}$ at $30{ }^{\circ} \mathrm{C}$. Subsequently the suspensions of cells were centrifuged at 2,000 x $\mathrm{g}$ for $5 \mathrm{~min}$., the supernatant was discarded and suspended in carbonate buffer (50 mM, pH 9.6) (39). Cell number was adjusted to $10^{8}$ cells $\mathrm{mL}^{-1}$ using the optical density at $496 \mathrm{~nm}$. The optical density technique was calibrated against the microcolony method (21).

Table 2. Cross reaction values of different strains of $\mathrm{N}_{2}$-fixing bacteria against Gluconacetobacter diazotrophicus antiserum.

\begin{tabular}{|c|c|c|c|c|}
\hline \multirow{3}{*}{ Bacterial strains } & \multicolumn{4}{|c|}{ Reaction (\%) } \\
\hline & \multicolumn{2}{|r|}{ Anti-PR2 } & \multicolumn{2}{|r|}{ Anti-PAL3 } \\
\hline & Unpurified & $\begin{array}{c}\text { Purified GB-pH } 3.0 \\
\left(0.640 \text { mg ptn } \mathrm{mL}^{-1}\right)\end{array}$ & Unpurified & $\begin{array}{l}\text { Purified GB-pH } 4.0 \\
\left(0.342 \mathrm{mg} \text { ptn } \mathrm{mL}^{-1}\right)\end{array}$ \\
\hline \multicolumn{5}{|l|}{ G. diazotrophicus } \\
\hline PR2 & 100.00 & 100.00 & 94.52 & 110.08 \\
\hline PAL3 & 97.88 & 142.95 & 100.00 & 100.00 \\
\hline PAL5 & 79.81 & 126.63 & 136.44 & 123.81 \\
\hline \multicolumn{5}{|c|}{ Sugar cane isolates of $G$. diazotrophicus } \\
\hline BR11324 & 90.21 & 91.37 & 82.30 & 85.4 \\
\hline BR11325 & 89.33 & 93.53 & 90.40 & 93.4 \\
\hline BR11326 & 97.62 & 98.24 & 91.25 & 94.2 \\
\hline BR 11331 & 94.84 & 97.39 & 95.47 & 97.5 \\
\hline \multicolumn{5}{|l|}{ Acetobacteriaceae } \\
\hline Gluconobacter oxidans & 25.12 & 16.32 & 20.60 & 8.16 \\
\hline Acetobacter hansenii & 30.42 & 20.02 & 29.67 & 15.05 \\
\hline A. aceti & 31.13 & 25.71 & 27.75 & 12.8 \\
\hline A. pasteurianus & 35.43 & 15.43 & 30.86 & 7.65 \\
\hline A. liquefaciens & 22.50 & 10.50 & 36.95 & 13.5 \\
\hline \multicolumn{5}{|l|}{ Herbaspirillum seropedicae } \\
\hline HRC54 & 0.01 & 0.00 & 1.47 & 0.85 \\
\hline Z67 & 6.36 & 0.00 & 2.38 & 0.56 \\
\hline Z94 & 4.24 & 0.00 & 6.62 & 1.20 \\
\hline \multicolumn{5}{|l|}{ H. rubrisubalbicans } \\
\hline HCC103 & 0.02 & 0.00 & 7.82 & 0.67 \\
\hline M4 & 8.21 & 3.15 & 5.91 & 0.35 \\
\hline B 4362 & 8.74 & 2.40 & 8.74 & 0.44 \\
\hline M1 & 7.81 & 1.60 & 10.46 & 7.54 \\
\hline \multicolumn{5}{|l|}{ Azospirillum brasilense } \\
\hline 107 & 0.00 & 0.00 & 7.21 & 1.54 \\
\hline Sp7 & 0.00 & 0.00 & 6.89 & 3.54 \\
\hline Sp245 & 0.00 & 0.00 & 9.87 & 0.08 \\
\hline \multicolumn{5}{|l|}{ Azospirillum. lipoferum } \\
\hline USA5b & 0.00 & 0.00 & 0.00 & 0.00 \\
\hline 59 & 0.00 & 0.00 & 0.00 & 0.00 \\
\hline $\mathrm{H} 21$ & 0.00 & 0.00 & 0.00 & 0.00 \\
\hline \multicolumn{5}{|l|}{ Azospirillum amazonense } \\
\hline Y6 & 18.74 & 10.04 & 20.59 & 0.015 \\
\hline CBamc & 19.50 & 12.16 & 22.75 & 0.017 \\
\hline Klebsiella sp. & 5.27 & 0.41 & 4.92 & 0.97 \\
\hline Alcaligenes faecalis & 8.52 & 2.40 & 7.89 & 1.25 \\
\hline Burkholderia vietnamensis & 6.44 & 1.68 & 7.80 & 2.59 \\
\hline \multicolumn{5}{|l|}{ Burkholderia tropica } \\
\hline PPe6 & 3.97 & 0.58 & 1.98 & 0.00 \\
\hline PPe8 & 2.82 & 0.00 & 2.25 & 0.00 \\
\hline
\end{tabular}

Experimental conditions: antigen: $10^{7}-10^{8}$ cells $\mathrm{mL}^{-1}$. Dilution of the primary antibody: without purification 1:1000 and with purification 1:10. Were used the $\mathrm{pH}$ fraction which the higher protein contain. Dilution of the secondary antibody: 1:3000 e 1:300 (without and with purification, respectively). Media of three replicates subtract of the negative control (pre-immune serum). 
Table 3. Cross reaction values of different strains of $\mathrm{N}_{2}$-fixing bacteria against Herbaspirillum seropedicae antiserum

\begin{tabular}{|c|c|c|c|c|}
\hline \multirow[b]{3}{*}{ Bacterial strains } & \multicolumn{4}{|c|}{ Reaction (\%) } \\
\hline & \multicolumn{2}{|c|}{ Anti-HRC54 } & \multicolumn{2}{|c|}{ Anti-Z67 } \\
\hline & Unpurified & 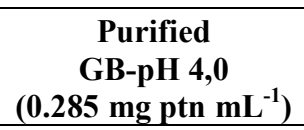 & Unpurified & $\begin{array}{c}\text { Purified } \\
\text { GB-pH 3,0 } \\
\left(0.473 \text { mg ptn } \mathrm{mL}^{-1}\right) \\
\end{array}$ \\
\hline \multicolumn{5}{|l|}{ H. seropedicae } \\
\hline HRC54 & 100.00 & 100.00 & 87.59 & 75.45 \\
\hline Z67 & 89.30 & 81.51 & 100.00 & 100.00 \\
\hline $\mathrm{HCC} 102$ & 114.00 & 98.08 & 88.00 & 71.32 \\
\hline HRC52 & 95.60 & 75.00 & 84.23 & 74.58 \\
\hline HRC80 & 96.52 & 85.89 & 75.91 & 72.66 \\
\hline HCC 100 & 97.20 & 79.34 & 85.28 & 77.16 \\
\hline \multicolumn{5}{|l|}{ H. rubrisubalbicans } \\
\hline HCC 103 & 49.66 & 4.23 & 46.86 & 17.05 \\
\hline M4 & 38.03 & 2.10 & 42.33 & 19.15 \\
\hline B4362 & 33.54 & 3.45 & 37.03 & 10.58 \\
\hline M1 & 44.59 & 12.50 & 31.85 & 8.59 \\
\hline \multicolumn{5}{|l|}{ G. diazotrophicus } \\
\hline PR2 & 9.58 & 0.52 & 7.32 & 0.24 \\
\hline PAL 5 & 7.65 & 0.69 & 10.94 & 0.58 \\
\hline PAL3 & 8.59 & 0.87 & 11.76 & 0.67 \\
\hline \multicolumn{5}{|l|}{ Burkholderia tropica } \\
\hline PPe6 & 10.54 & 0.25 & 8.79 & 1.6 \\
\hline PPe 8 & 11.58 & 0.01 & 9.25 & 5.2 \\
\hline \multicolumn{5}{|l|}{ Burkholderia sp. } \\
\hline M130 & 8.65 & 1.47 & 10.59 & 0.48 \\
\hline \multicolumn{5}{|c|}{ Azospirillum amazonense } \\
\hline CBamc & 23.89 & 10.58 & 27.84 & 8.66 \\
\hline Y6 & 25.87 & 10.82 & 30.25 & 14.82 \\
\hline \multicolumn{5}{|l|}{ Azospirillum lipoferum } \\
\hline $\mathrm{Sp} 59$ & 15.18 & 3.85 & 10.71 & 5.41 \\
\hline \multicolumn{5}{|l|}{ Azospirillum brasilense } \\
\hline $\mathrm{Sp} 7$ & 9.98 & 1.70 & 22.50 & 11.13 \\
\hline
\end{tabular}

\section{Minimal detection limit}

Cells of the strains used to produce the antibodies where diluted from $10^{8}$ to $10^{3}$ and the ELISA protocol was performed. To calculate the true number of bacterial cells, 20 $\mu \mathrm{L}$ of each dilution was counted using the microcolony procedure with three replicates. The plates were incubated at $30{ }^{\circ} \mathrm{C}$ until initial colony growth was observed. The total number of colonies obtained in all three drops was divided by three and multiplied by 50 and the corresponding dilution factor.

\section{Plant material}

Stems cuttings (setts) of sugar cane (Saccharum spp.) were collected from the Experimental Station of EmbrapaAgrobiologia, Seropédica, Rio de Janeiro. The variety sampled was SP 70-1143 planted in the field which had been growing for several years without nitrogen addition. Roots, rhizomes, stems and leaves were sampled. Setts with single nodes were planted in sterile sand/vermiculite (2:1) and maintained in the greenhouse. A total of 32 setts were planted and 16 were sampled at germination and the others at 16 and 40 days after planting. 
Table 4. Cross reaction values of different strains of $\mathrm{N}_{2}$-fixing bacteria against Herbaspirillum rubrisubalbicans antiserum.

\begin{tabular}{|c|c|c|c|c|}
\hline \multirow{3}{*}{ Bacterial strains } & \multicolumn{4}{|c|}{ Reaction (\%) } \\
\hline & \multicolumn{2}{|c|}{ Anti-HCC103 } & \multicolumn{2}{|r|}{ Anti-M4 } \\
\hline & Unpurified & $\begin{array}{c}\text { Purified } \\
\text { pH 4.0 } \\
{\left[0.330 \mathrm{mg} \mathrm{ptn} \mathrm{mL}^{-1}\right]}\end{array}$ & Unpurified & $\begin{array}{c}\text { Purified } \\
\text { pH 3.0 } \\
{\left[0.609 \text { mg ptn } \mathrm{mL}^{-1}\right]}\end{array}$ \\
\hline \multicolumn{5}{|l|}{ H. rubrisubalbicans } \\
\hline HCC103 & 100.00 & 100.00 & 93.31 & 77.27 \\
\hline M4 & 165.86 & 95.0 & 100.00 & 100.00 \\
\hline B 4362 & 102.61 & 100.29 & 86.95 & 81.82 \\
\hline M1 & 100.55 & 72.73 & 85.65 & 70.45 \\
\hline \multicolumn{5}{|l|}{ H. seropedicae } \\
\hline HRC54 & 38.25 & 10.95 & 96.97 & 79.63 \\
\hline Z67 & 28.62 & 1.32 & 103.63 & 68.17 \\
\hline HCC102 & 25.48 & 8.92 & 107.53 & 97.23 \\
\hline HRC52 & 24.56 & 6.58 & 85.47 & 62.09 \\
\hline HRC80 & 20.40 & 5.87 & 105.80 & 54.55 \\
\hline HCC100 & 27.46 & 1.53 & 66.50 & 54.54 \\
\hline \multicolumn{5}{|l|}{ G. diazotrophicus } \\
\hline PR2 & 8.9 & 0.0 & 13.29 & 0.21 \\
\hline PAL 5 & 7.6 & 0.0 & 17.94 & 0.01 \\
\hline PAL3 & 21.34 & 0.0 & 22.94 & 0.00 \\
\hline \multicolumn{5}{|l|}{ Burkholderia tropica } \\
\hline PPe6 & 0.00 & 0.00 & 0.00 & 0.00 \\
\hline PPe8 & 0.00 & 0.00 & 0.00 & 0.00 \\
\hline \multicolumn{5}{|l|}{ Burkholderia sp. } \\
\hline M130 & 6.67 & 0.59 & 8.45 & 2.73 \\
\hline \multicolumn{5}{|l|}{ Azospirillum lipoferum } \\
\hline $\mathrm{Sp} 59$ & 9.83 & 0.00 & 3.09 & 0.0 \\
\hline \multicolumn{5}{|l|}{ Azospirillum brasilense } \\
\hline $\mathrm{Sp} 7$ & 4.78 & 0.25 & 21.04 & 8.34 \\
\hline \multicolumn{5}{|l|}{ Azospirillum amazonense } \\
\hline Cbamc & 0.00 & 0.00 & 0.00 & 0.00 \\
\hline Y6 & 37.3 & 13.08 & 30.42 & 10.45 \\
\hline
\end{tabular}

Plant parts were macerated, diluted in phosphate saline buffer (PBS) and the bacterial numbers were counted using the indirect ELISA procedure, and the Most Probable Number technique using semi-solid LGI-P media supplemented with $5 \mathrm{~mL} \mathrm{~L}^{-1}$ of cane juice (30) for $G$. diazotrophicus, and JNFb (24) for Herbaspirillum spp. using 5 vials per dilution $\left(10^{-2}\right.$ to $\left.10^{-7}\right)$ and applying the McCrady table (28).

\section{ELISA using plant material}

Roots and aerial parts were washed in tap water, separated into two fractions of $1.0 \mathrm{~g}$ each. One fraction was immersed in $1 \%$ chloramine $\mathrm{T}$ for $5 \mathrm{~min}$ for surface sterilisation, and the other was maintained in distilled water for $1 \mathrm{~h}$. After this treatment, plant material was washed in PBS and transferred to sterile water (1h). All the plant material was macerated in $9.0 \mathrm{~mL}$ of PBS. To this macerated material was added $0.2 \mathrm{~g}$ of poly-ethylene-glycol (PEG 6000Sigma) and $0.2 \mathrm{~g}$ of Chelex 100 (ionic resin-Sigma) to eliminate organic and ionic bonds respectively. This material 
was incubated one hour, agitated at $4{ }^{\circ} \mathrm{C}$ and then filtered through a coarse porcelain filter to eliminate the larger particles of plant material. After that a Swinnex support with $25 \mathrm{~mm}$ diameter (Millipore) was used filled with 3 different paper filters: paper filter used to filter coffee (Melitta do Brasil Indústria e Comércio LTDA, Brazil), $26 \mu \mathrm{m}$ paper filter (Framex 3891, Scheider \& Schull, Germany) and $8 \mu \mathrm{m}$ paper filter (Whatman 40, W \& R Bolston Limited, England). This procedure eliminated plant debris and the resin and also facilitated the last filtration using a $5 \mu \mathrm{m}$ filter (Sartorius, AG, Goettingen, Germany) to eliminate plant debris larger than bacterial cells. The filtered suspension was then centrifuged $5,000 \times \mathrm{g}$ for $5 \mathrm{~min}$ at $4{ }^{\circ} \mathrm{C}$ and suspended in 1 $\mathrm{mL}$ PBS. To inactivate any endogenous peroxidase enzyme present in the plant tissue, $1.5 \mathrm{~mL}$ of paraformaldehyde was used (4\% solution in PBS) for $2 \mathrm{~h}$ at room temperature. After this incubation period, the material was centrifuged (same conditions as cited above) and the bacterial cells were suspended in carbonate buffer $(50 \mathrm{mM}, \mathrm{pH} 9.6)$. After this step, the indirect ELISA protocol used was described above. We used 3 replicates for each treatment. In all plates used, several control treatments were performed including the preimmune serum in the presence of the plant extract, and all steps except the primary antibody or the secondary antibody. The ratio of cell number to absorbance was determined using the target bacteria in dilutions from $10^{8}$ to $10^{3}$ cells $\mathrm{mL}^{-1}$.

\section{RESULTS AND DISCUSSION}

Eight weeks after inoculating the rabbits, all six sera had the highest titre value at a dilution of the antibody of 10,000 (data not shown), and this dilution was used in further tests where unpurified sera were used. After purification with protein-A, it was necessary to use lower dilutions of the antibodies as shown in Figure 1. The protein contents after purification were different at the two different $\mathrm{pH}$ values, even for the same bacterial species. The minimum detection limit observed for all sera produced was $10^{5}$ cells $\mathrm{mL}^{-1}$ using either purified or unpurified sera (data not show). This limit is similar to that reported by $\mathrm{Li}$ and MacRae (19) for the sera they produced for Gluconacetobacter diazotrophicus. Reis et al. (31) obtained same results with antibodies produced against $H$. rubrisubalbicans (strain M4), but the antibodies produced against $H$. seropedicae (strain Z67) had a minimum detection limit of $10^{6}$ cells $\mathrm{mL}^{-1}$. To enhance the detection limit, Schloter and Hartmann (37) used monoclonal antibodies with high levels of reactivity against a single specific epitope and were able to detect a positive signal down to $5 \times 10^{3}$ cells $\mathrm{mL}^{-1}$ of Azospirillum brasilense strain Sp 245, using chemiluminescent ELISA. Nambiar and Anjaiah (22) reported the detection of as few as $10^{2}-10^{3}$ cells of rhizobia, while Martensson et al. (20) detected $10^{3}$ cells $\mathrm{mL}^{-1}$ of Rhizobium meliloti. However, in these latter two cases, no test of cross reactivity was performed. Decreasing IgG and conjugate dilution levels, increases the specificity but it is accompanied by a decrease in sensitivity (19).

The cross-reactions of purified and crude sera of $G$. diazotrophicus with other bacteria are shown in Table 2. All strains of $G$. diazotrophicus showed reactions of over $80 \%$ of the absorbance of the strain used to prepare the serum, and in all but 3 cases out of 28 , this cross-reaction was over $90 \%$. For the unpurified sera cross-reactions with other species within the same family (Acetobacteriaceae) were lower than $40 \%$, and for purified sera lower than $26 \%$. Similar results were obtained by $\mathrm{Li}$ and MacRae (19) with the sera developed for $G$. diazotrophicus strain 1 S 16.5 which showed the highest cross-reaction against one strain of Acetobacter pasteurianus (35\%) and lower to two strains of A. aceti (31 and $19 \%$ ) and one strain of Gluconobacter oxydans (16 \%). The other species tested had a lower absorbance value, below $10 \%$ with the exception of Azospirillum amazonense, which for unpurified sera showed values as high as $23 \%$. This was not expected, and even after purification the cross reaction with the PR2 serum still remained above $10 \%$, showing that this species share some common epitopes with the strain PR2 but not with PAL3. However, with these results, these two sera were considered species-specific. These cross-reactions may be of value for 

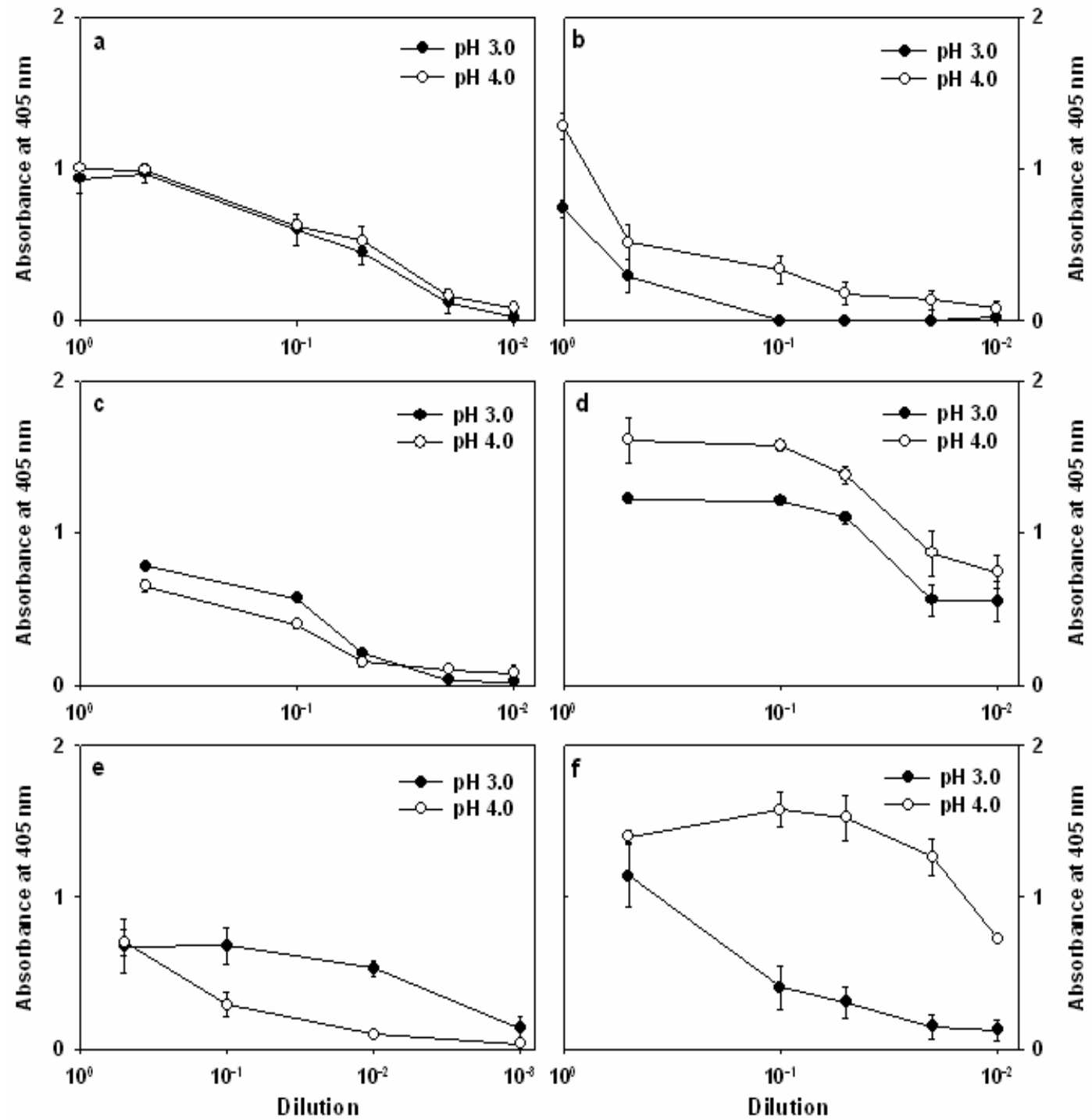

Figure 1. Titre of the polyclonal antibodies produced against the species G. diazotrophicus, H. seropedicae and $H$. rubrisubalbicans. Primary antibodies (PA) used: anti-PR2 [GB-pH 3.0 (ptn $0.640 \mathrm{mg} \mathrm{mL}^{-1}$ ) and GB-pH 4.0 (ptn 0.205 mg mL ${ }^{1}$ )]; anti-PAL3 [GB-pH 3.0 (ptn $0.255 \mathrm{mg} \mathrm{mL}^{-1}$ ) and GB-pH 4.0 (ptn $0.342 \mathrm{mg} \mathrm{mL}^{-1}$ )]; anti-Z 67 [GB-pH 3.0 (ptn $0.473 \mathrm{mg}$ $\mathrm{mL}^{-1}$ ) and GB-pH 4.0 (ptn $0.362 \mathrm{mg} \mathrm{mL}^{-1}$ )]; anti-HRC54 [GB-pH 3.0 (ptn $0.115 \mathrm{mg} \mathrm{mL}^{-1}$ ) and GB-pH 4.0 (ptn 0.285 mg mL $\left.{ }^{1}\right)$ ]; anti-M4 [GB-pH 3.0 (ptn $0.609 \mathrm{mg} \mathrm{mL}^{-1}$ ) and GB-pH 4.0 (ptn- $0.382 \mathrm{mg} \mathrm{mL}^{-1}$ )]; anti-HCC103 [GB-pH 3.0 (ptn 0.117 mg $\mathrm{mL}^{-1}$ ) and GB-pH 4.0 (ptn $0.330 \mathrm{mg} \mathrm{mL}^{-1}$ )]. The concentrations of antigens used were $10^{8}$ cell $\mathrm{mL}^{-1}$. Secondary antibody (SA) dilution was 1:300. The incubations with the antibodies were processed at $37{ }^{\circ} \mathrm{C}$ for $30 \mathrm{~min}$ to PA and for $45 \mathrm{~min}$ to SA, after rotation at $300 \mathrm{rpm}$ for $3 \mathrm{~min}$. Reaction time with the ABTS substrate were inferior for 9 min at $100 \mathrm{rpm}$. Means of 4 replicates. The absorbance of the pre-immune serum was subtracted from the absorbance of the samples. Absorbance read at $\lambda=405 \mathrm{~nm}$. 
revealing relatedness of different strains (1) and can be also used for grouping analysis $(12,34)$.

Both antisera produced for Herbaspirillum seropedicae shared some common antigenic determinants with $H$. rubrisubalbicans but these reactions were decreased considerably after protein-A purification and these antibodies can also be considered to be species-specific (Table 4). In the case of $H$. rubrisubalbicans, the polyclonal antibodies produced against strain $\mathrm{HCC} 103$ can be considered as species-specific but the other antibody produced against strain M4 showed a very high cross-reaction signal against strains of H. seropedicae even after purification (Table 5). However, this antibody showed very low cross-reaction against other bacteria and thus can be considered genera- specific. For both antibodies, the purification made very significant improvements in specificity, especially with respect to their cross-reactivity with the closely related $H$. rubrisubalbicans. The cost of this improvement in specificity is the use of protein-A column. This results are considered good if compared to those obtained by Reis et al. (31) when after purification using a protein-A column of both antibodies produced against $H$. seropedicae (strain Z67) and $H$. rubrisubalbicans (strain M4) showed a high level of interspecific cross-reactivity. Reis et al. (31) used UV radiation to kill the bacteria, a technique which does not eliminate proteins of the flagella. The thermal treatment used by us does eliminate these proteins and is probably responsible for the greater specificity of our antibodies (29).

Table 5. Comparison of methods of bacterial counts using the MPN and indirect modified ELISA present in sugar cane variety SP 70-1143 with 12 months old. Cell number per $g$ fresh weight. Values are means of four replicate samples

a) Antiserum and antibodies against G. diazotrophicus (anti-PR2, pH 3.0)

\begin{tabular}{lcccc}
\hline \multirow{2}{*}{ Samples } & \multicolumn{2}{c}{ MPN } & \multicolumn{2}{c}{ ELISA } \\
\cline { 2 - 4 } roots & sterilised & not sterilised & sterilised & Not sterilised \\
rhizome & $4.5 \times 10^{5}$ & $3.0 \times 10^{6}$ & $9.0 \times 10^{5}$ & $4.0 \times 10^{7}$ \\
leaves & $1.4 \times 10^{4}$ & $1.5 \times 10^{5}$ & $4.9 \times 10^{5}$ & $5.9 \times 10^{6}$ \\
\hline
\end{tabular}

b) Antiserum and antibodies against Herbaspirillum seropedicae (anti-HRC54, GB-pH 4.0) and Herbaspirillum rubrisubalbicans (anti-HCC103, GB-pH 4.0)

\begin{tabular}{lcccccc}
\hline \multirow{2}{*}{ Samples } & \multicolumn{2}{c}{ MPN } & \multicolumn{3}{c}{ ELISA } \\
\cline { 2 - 6 } & sterilised & $\begin{array}{c}\text { not } \\
\text { sterilised }\end{array}$ & \multicolumn{2}{c}{ sterilised } & not sterilised \\
\cline { 3 - 7 } & & & anti-HRC54 & anti- HCC103 & anti-HRC54 & anti- HCC103 \\
\hline roots & $1.6 \times 10^{4}$ & $2.0 \times 10^{5}$ & $1.9 \times 10^{6}$ & $3.6 \times 10^{6}$ & $1.3 \times 10^{7}$ & $2.4 \times 10^{6}$ \\
rhizome & $4.0 \times 10^{3}$ & $3.5 \times 10^{5}$ & $1.2 \times 10^{5}$ & N.D. & $4.2 \times 10^{6}$ & $6.8 \times 10^{5}$ \\
leaves & $1.1 \times 10^{4}$ & $9.5 \times 10^{4}$ & N.D. & $7.4 \times 10^{5}$ & N.D. & $3.9 \times 10^{6}$ \\
\hline
\end{tabular}

* Means of four replicates

N.D. Not detected 
In this study the populations of all three diazotrophs ( $G$. diazotrophicus, H. seropedicae and H. rubrisubalbicans) were quantified simultaneously using the ELISA procedure outlined above and the results compared to those obtained with the MPN technique (Table 5). For this quantification field-grown 12-month old sugar cane plants (variety SP 701143) were sampled and separated into roots, rhizomes and leaves. As expected, the ELISA procedure always yielded estimates higher than those determined by MPN, from 2 to 1429 times greater in the case of $G$. diazotrophicus and between 2 and 225 times for the Herbaspirillum species.

Comparing the two bacteria counted by both methods (ELISA and MPN), the populations of G. diazotrophicus were underestimated to a greater degree than those of Herbaspirillum species. This may be due to the LGI-P medium used in the quantification of G. diazotrophicus (30). This medium uses a high sugar concentration $\left(100 \mathrm{~g} \mathrm{~L}^{-1}\right)$ and pH 5.5 - 5.7, which enhances selectivity when compared to the $\mathrm{JNFb}$ medium (malate $5 \mathrm{~g} \mathrm{~L}^{-1}$ and $\mathrm{pH}$ 5.8) for Herbaspirillum. During the growth of G. diazotrophicus on LGI-P the $\mathrm{pH}$ of the medium falls to less than 3.0 which render this medium as highly selective. Also the underestimation observed by the MPN may perhaps be attributed to the interference of other bacteria as observed by Reis et al. (30).

In another trial, the natural populations of $H$. seropedicae in the cane stems were quantified using the antibodies antiHRC54 purified by the protein-A column and the results were lower that those observed for $G$. diazotrophicus $\left(4.6 \times 10^{5}\right.$ cells $\mathrm{g}^{-1}$ fresh material) (Figure $2 \mathrm{a}$, control). Twenty days after germination this population increased 16 times reaching $2.4 \times 10^{8}$ cells g-1 fresh material in the roots and $2.4 \times 10^{8}$ cells g-1 fresh material of aerial parts 40 days after and superior to the numbers counted for $G$. diazotrophicus.

The natural population of Gluconacetobacter diazotrophicus present in the stems of sugar cane variety SP 70-1143 before germination using antibodies against strain PAL 3 was estimated to be $5.6 \times 10^{5}$ cell $\mathrm{g}^{-1}$ of fresh material. After, this stems were separated to be used as planting material (setts) and planted in a sterile substrate (vermiculite + sand) and 20 days after germination this number increased to $6.8 \times 10^{6}$ cells $\mathrm{g}^{-1}$ achieving $7.9 \times 10^{7}$ cells $\mathrm{g}^{-1}$ of fresh material 40 days after (Figure 2b). The presence of the $G$. diazotrophicus in the leaves appeared 40 days after and the population was $6.3 \times 10^{6}$ cells $^{-1}$ of fresh material.
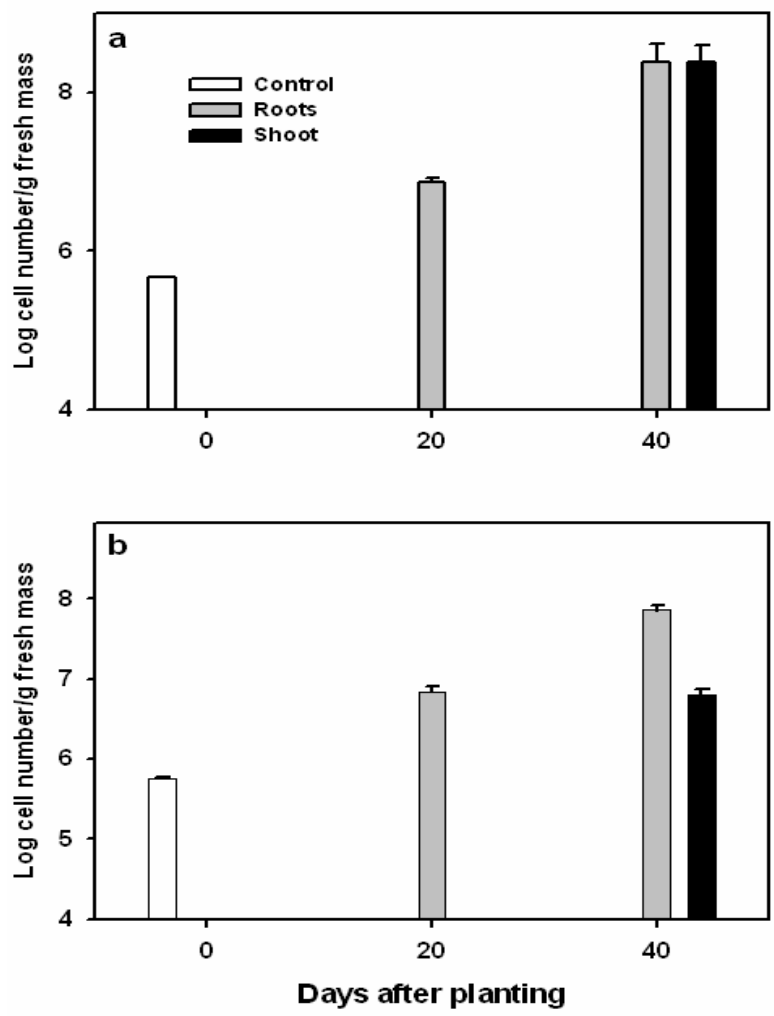

Figure 2. Populations of Herbaspirillum seropedicae (a) and Gluconacetobacter diazotrophicus (b) present in germinated setts determined by the modified Indirect ELISA method. These antibodies were obtained after purification using glycine buffer solution $[\mathrm{GB}]$ in a protein-A column. Primary antibodies (PA) used

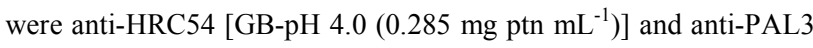
[GB-pH $4.0\left(0.342 \mathrm{mg}\right.$ ptn $\left.\mathrm{mL}^{-1}\right)$ ]. Both were diluted 1:10. Secondary antibody (SA) dilution was 1:300. The incubations with the antibodies were processed at $37^{\circ} \mathrm{C}$ for $30 \mathrm{~min}$ to PA and for 45 min to SA, after rotation at $300 \mathrm{rpm}$ for $3 \mathrm{~min}$. Reaction time with the ABTS substrate were inferior for $9 \mathrm{~min}$ at $100 \mathrm{rpm}$. Means of 4 replicates The absorbance of the pre-immune serum was subtracted from the absorbance of the samples. Control values refer to the stems before germination. Absorbance read at $\lambda=405 \mathrm{~nm}$. 
Comparing different plant parts of sugar cane variety SP 70-1143, in 12-month-old plants, the bacterial numbers were higher in the roots and rhizome part and in both cases, the natural population of $G$. diazotrophicus were higher, reaching $6.8 \times 10^{7}$ cells $\mathrm{g}^{-1}$ fresh material in the roots and $3.2 \times 10^{7}$ cells $\mathrm{g}^{-1}$ fresh material in the rhizome compared to the numbers of $H$. seropedicae $\left(5.4 \times 10^{6}\right.$ cells $\mathrm{g}^{-1}$ fresh material in the root and $7.2 \times 10^{5}$ cells $\mathrm{g}^{-1}$ fresh material in the rhizome). The natural populations of $G$. diazotrophicus and $H$. seropedicae obtained in the stems and leaves were similar but much lower than in the roots (Figure 3). Li and MacRae (19) found similar results for G. diazotrophicus. Our results confirm the observation made by these authors where they speculate that the multiplication of $G$. diazotrophicus was mainly restricted to the developing sugar cane tissue as observed by the numbers obtained after germination of the setts (Figure 3). Furthermore, this work constitutes the first report of the quantification of the populations of Herbaspirillum spp. in plants using immunological methods.

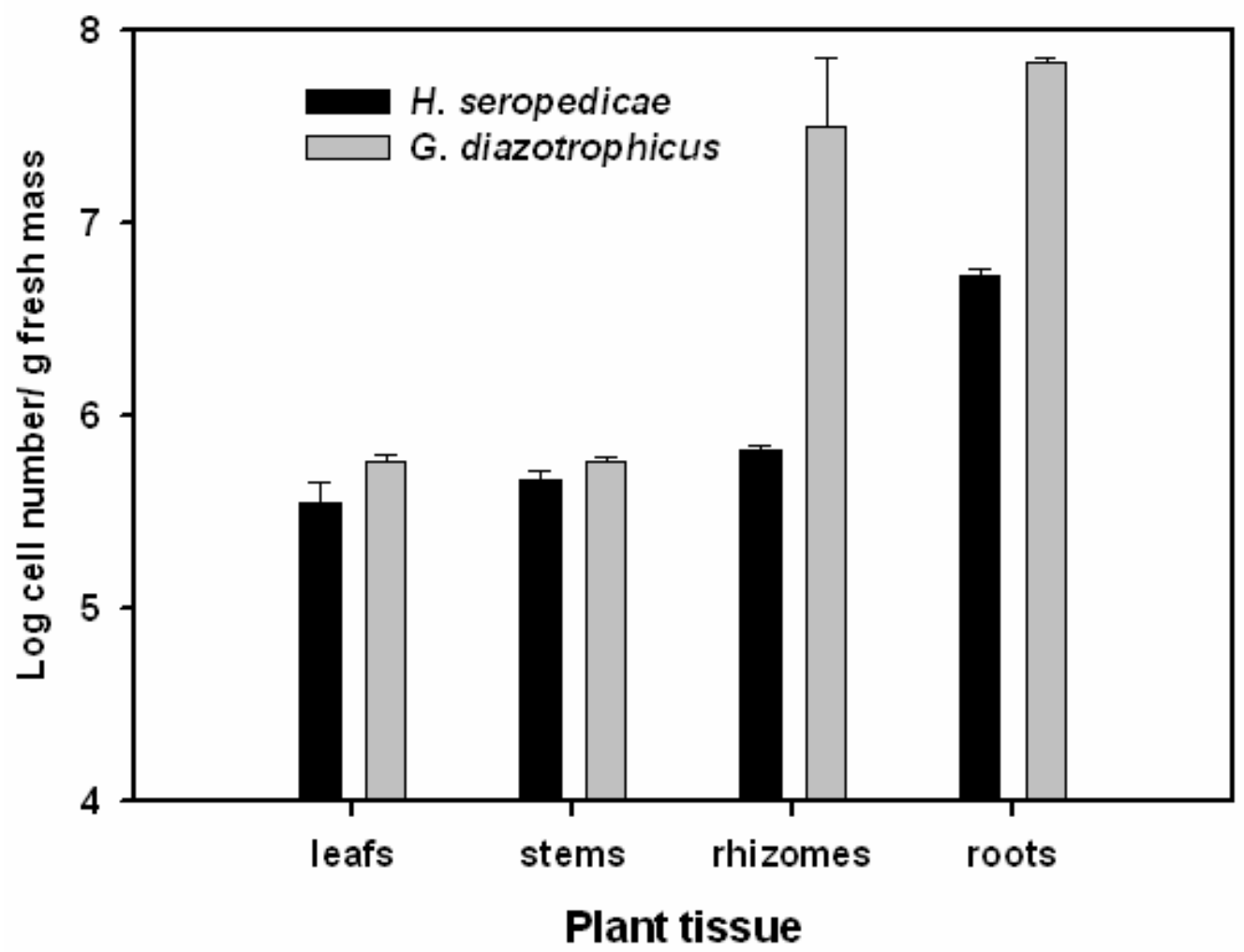

Figure 3. Population of $H$. seropedicae and G. diazotrophicus present in adult plants evaluated using the modified Indirect ELISA method. These antibodies were obtained after purification using glycine buffer solution (GB) in a protein-A column. Primary antibodies (PA) used were anti-HRC54 [GB-pH $4.0\left(0.285 \mathrm{mg} \mathrm{ptn} \mathrm{mL}^{-1}\right)$ ] and anti-PAL3 [GB-pH $4.0(0.342 \mathrm{mg}$ ptn $\left.\mathrm{mL}^{-1}\right)$ ]. Both were diluted 1:10. Secondary antibody (SA) dilution was 1:300. The incubations with the antibodies were processed at $37^{\circ} \mathrm{C}$ for $30 \mathrm{~min}$ to $\mathrm{PA}$ and for $45 \mathrm{~min}$ to SA, after rotation at $300 \mathrm{rpm}$ for $3 \mathrm{~min}$. Reaction time with the ABTS substrate were inferior for $9 \mathrm{~min}$ at $100 \mathrm{rpm}$. Mean of 4 replicates. The absorbance of the pre-immune serum was subtracted from the absorbance of the samples. Control values refer to the stems before germination. Absorbance read at $\lambda=405 \mathrm{~nm}$. 


\section{ACKNOWLEDGEMENTS}

The authors would like to thank Geraldo B. da Cruz for valuable technical assistance and the Brazilian National Research Council (CNPq), the Rio de Janeiro State Research Foundation (FAPERJ) for research fellowships (Bolsa Cientista do Nosso Estado). This research was funded by Embrapa and PRONEX/FINEP.

\section{REFERENCES}

1. Ahmad, M.H.; Eaglesham, A.R.J.; Hassouna, S. (1981). Examining serological diversity of cowpea rhizobia by the ELISA technique. Arch. Microbiol. 130 (4), 281-287.

2. Bachhawat, A.K.; Ghosh, S. (1987). Isolation and characterization of the outer-membrane proteins of Azospirillum brasilense. J. Gen. Microbiol. 133 (7), 1751-1758.

3. Baldani, J.I.; Baldani, V.L.D.; Seldin, L.; Döbereiner, J. (1986). Characterization of Herbaspirillum seropedicae gen. nov., sp. nov., a root associated nitrogen-fixing bacterium. Int. J. Syst. Bacteriol. 36 (1), 86-93.

4. Baldani, J.I.; Caruso, L.; Baldani, V.L.D.; Goi, S.R.; Döbereiner, J. (1997). Recent advances in BNF with non-legume plants. Soil Biol. Biochem. 29 (5-6), 911-922.

5. Baldani, J.I.; Pot, B.; Kirchhof, G.; Falsen, E.; Baldani, V.L.D.; Olivares, F.L.; Hoste, B.; Kersters, K.; Hartmann, A.; Gillis, M.; Döbereiner, J. (1996). Emended description of Herbaspirillum; inclusion of [Pseudomonas] rubrisubalbicans, a mild plant pathogen, as Herbaspirillum rubrisubalbicans comb. nov.; and classification of a group of clinical isolates [EF Group1] as Herbaspirillum species 3. Int. J. Syst. Bacteriol. 46 (3), 802-810.

6. Baldani,V.L.D.; Baldani, J.I.; Olivares, F.; Döbereiner, J. (1992). Identification and ecology of Herbaspirillum seropedicae and the closely related Pseudomonas rubrisubalbicans. Symb. 13 (1-3), 65-73.

7. Barraquio, W.L.; Ladha, J.K.; Yao, H.Q.; Watanabe, I. (1986). Antigenic relationship of $\mathrm{N}_{2}$-fixing Pseudomonas strain $\mathrm{H} 8$ to various known cultures and rice rhizosphere isolates studied by indirect enzyme-linked immunosorbent assay [ELISA]. Can. J. Microbiol. 32 (5), 402-408

8. Barraquio, W.L.; Revilla, L.; Ladha, J.K. (1997). Isolation of endophytic diazotrophic bacteria from wetland rice. Pl. Soil 194 (1-2), $15-24$.

9. Boddey, R.M.; Silva, L.G. da; Reis, V.M.; Alves, B.J.R.; Urquiaga, S. (2000). Assessment of bacterial nitrogen fixation in grass species. In: Triplett E. (ed.) Prokaryotic nitrogen fixation: a model system for the analysis of a biological process. Horizon Scientific Press, Wymondham, Norfolk, UK, p. 705-726.

10. Caballero-Mellado, J.; Martinez-Romero, E. (1994). Limited genetic diversity in the endophytic sugarcane bacterium Acetobacter diazotrophicus. Appl. Environ. Microbiol. 60 (5), 1532-1537.

11. Cavalcante, V.A.; Döbereiner, J (1988). A new acid-tolerant nitrogenfixing bacterium associated with sugarcane. Pl. Soil 108 (1), 23-31.

12. Gray, T.R.G.; Mansoor, E.Y. (1996). The application of serological techniques to the taxonomy of Arthrobacter and related organism. Microbiology 142 (3), 561-573.

13. Gillis, M.; Kersters, K.; Hoste, B.; Janssens, D.; Kronppenstedt, R.M.; Stephan, M.P.; Teixeira, K.R. dos S.; Döbereiner, J.; De Ley, J. (1989). Acetobacter diazotrophicus sp. nov., a nitrogen-fixing acetic acid bacterium associated with sugarcane. Int. J. Syst. Bacteriol. 39 (3), 361 364.

14. Harlow, E.; Lane, D. (1988). Using antibodies - A laboratoty manual. Cold Spring Harbor, New York, 1st ed. 726p.

15. James, E.K.; Olivares, F.L.; Baldani, J.I.; Döbereiner, J. (1997) Herbaspirillum, an endophytic diazotroph colonizing vascular tissue in leaves of Sorghum bicolor L. Moench. J. Exp. Bot. 48 (308), 785-797.

16. James, E.K.; Olivares, F.L.; Oliveira, A.L.M.; Reis Jr., F.B.; Silva, L.G.; Reis, V.M. J. (2001). Further observations on the interaction between sugar cane and Gluconacetobacter diazotrophicus under laboratory and greenhouse conditions. J. Exp. Bot. 52 (357), 747-760.

17. Levanony, H.; Bashan, Y.; Kahana, Z. (1987). Enzyme-linked immunosorbent-assay for specific identification and enumeration of Azospirillum brasilense Cd. in cereal roots. Appl. Environ. Microbiol. 53 (2), 358-364

18. Lommel, S.A.; Mccain, A.H.; Morris, T.J. (1982). Evaluation of indirect enzyme-linked immunosorbent-assay for the detection of plantviruses. Phytopathology 72 (8), 1018-1022.

19. Li, R.; MacRae, I.C. (1992). Specific identification and enumeration of Acetobacter diazotrophicus in sugarcane. Soil Biol. Biochem. 24 (5), 413-419.

20. Martensson, A.M.; Gustafsson, J.G.; Ljunggren, H.D. (1984). A modified, highly sensitive enzyme-linked immunosorbent-assay (ELISA) for Rhizobium meliloti strain identification. J. Gen. Microbiol. 130 (2), 247-253.

21. Miles, A.A.; Misra, A.A. (1938). The estimation of the bactericidal power of blood. J. Hyg. 38(6), 732-749.

22. Nambiar, P.T.C.; Anjaiah, V. (1985). Enumeration of rhizobia by enzyme-linked immunosorbent-assay (ELISA). J. Appl. Bacteriol. 58 (2), 187-193.

23. Olivares, F.L. (1997). Taxonomia, ecologia e mecanismos envolvidos na infecção e colonização de plantas de cana-de-açúcar (Saccaharum spp. híbrido) por bactérias diazotróficas endofiticas do gênero Herbaspirillum. Seropédica, RJ, Brasil, 328 p. (Tese de Doutorado. Departamento de Solos, Instituto de Agronomia, UFRRJ). 
24. Olivares, F.L.; Baldani, V.L.D.; Reis, V.M.; Baldani, J.I.; Döbereiner, J. (1996). Occurrence of the endophytic diazotrophs Herbaspirillum spp. in roots, stems, and leaves, predominantly of Graminea. Biol. Fertil. Soils 21 (3), 197-200.

25. Olivares, F.L.; James, E.K.; Baldani, J.I.; Döbereiner, J. (1997). Infection of mottled stripe disease-susceptible and resistant sugar cane varieties by the endophytic diazotroph Herbaspirillum. New Phytol. 135 (4), 723-737.

26. Oliveira, A.L.M.; Canuto, E.L.; Silva, E.E.; Reis, V.M.; Baldani, J.I. (2004). Survival of endophytic diazotrophic bacteria in soil under different moisture levels. Braz. J. Microbiol. 35:395-299.

27. Olsen, P.E.; Rice, W.A. (1989). Rhizobium strain identification and quantification in commercial inoculants by immunoblot analysis. Appl. Environ. Microbiol. 55 (2), 520-522.

28. Pochon, J.; Tardieux, P. (1962). Techniques d'analyse en microbiologie du sol. St. Mandé (Sein), Editions de la Tourelle, 105p.

29. Rajapakse, S.; MacGregor, A.N. (1992). Serological analysis of Rhizobium meliloti strains used in commercial alfalfa inoculants in New Zealand. N. Z. J. Agric. Res. 35 (3), 355-358.

30. Reis, V.M.; Olivares, F.L.; Döbereiner, J. (1994). Improved methodology for isolation of Acetobacter diazotrophicus and confirmation of its endophytic habitat. World J. Microbiol. Biotechnol. $10(4), 401-405$

31. Reis, V.M.; Reis Júnior, F.B. dos; Salles, J.F.; Schloter, M. (2000). Characterisation of different polyclonal antisera to quantify Herbaspirillum spp. in elephant grass (Pennisetum purpureum Schun.). Symb. 29 (2), 139-150.

32. Reis, V.M.; Reis Júnior F.B. dos; Quesada, D.M.; Oliveira, O.C. de; Alves, B.J.R.; Urquiaga, S.; Boddey, R.M. (2001). Biological nitrogen fixation associated with tropical pasture grasses. Aust. J. Plant Physiol. 28 (9), 837-844.

33. Reis Júnior, F.B. dos; Reis, V.M.; Urquiaga, S.; Döbereiner, J. (2000). Influence of nitrogen fertilisation on the population of diazotrophic bacteria Herbaspirillum spp. and Acetobacter diazotrophicus in sugar cane (Saccharum spp.). Pl. Soil, 219 (1-2), 153-159.

34. Reis Júnior, F.B. dos; Silva, M.G. da; Teixeira, K.R.dos S.; Urquiaga, S.; Reis, V.M. (2004). Intra-specific diversity study of the nitrogen fixing bacterium Azospirillum amazonense isolated from different Brachiaria species. Symb. 36 (1), 41-56.

35. Rodrigues Neto, J.; Malavolta Jr., V.A.; Victor, O. (1986). Meio simples para o isolamento e cultivo de Xanthomonas campestris pv. citri Tipo B. Summa Phytopathol. 12(1-2), 32.

36. Schloter, M.; Bode, H.; Hartmann, A.; Beese, F. (1992) Sensitive chemoluminescence-based immunological quantification of bacteria in soil extracts with monoclonal antibodies. Soil Biol. Biochem. 24 (5) 399-403.

37. Schloter, M.; Hartmann, A. (1996). Production and characterization of strain-specific monoclonal antibodies against outer membrane components of Azospirillum brasilense Sp 245. Hybrid. 15 (3), 225232.

38. Schloter, M.; Moens, S.; Croes, C.; Reidel, G.; Esquenet, M.; Demot, R.; Hartmann, A.; Michielis, K. (1994). Characterization of cell-surface components of Azospirillum brasilense $\mathrm{Sp} 7$ as antigenic determinants for strain-specific monoclonal-antibodies. Microbiol. 140 (4), 823-828.

39. Schloter, M.; Wiehe, W.; Assmus, B.; Steindl, H.; Becke, H.; Höflich, G.; Hartmann, A. (1997). Root colonization of different plants by plantgrowth-promoting Rhizobium leguminosarum bv. trifolii R39 studied with monospecific polyclonal antisera. Appl. Environ. Microbiol. 63 (5), 2038-2046

40. Silva, L.G. da. (1999). Estudos de colonização em cana-de-açúcar (Saccharum spp.) por Gluconacetobacter diazotrophicus e Herbaspirillum spp. utilizando técnicas imunológicas. Seropédica, RJ, Brasil. 122p. (M.Sc. Dissertation. Instituto de Agronomia. UFRRJ).

41. Silva, L. G. da; Miguens, F. C.; Olivares, F. L. (2003) Herbaspirillum seropedicae and sugarcane endophytic interaction investigated by using High Pressure Freezing Electron Microscopy. Braz. J. Microbiol. 34 spl. (1), 69-71.

42. Tajini. F.; Drevon, J.J.; Lamouchi, L.; Aouani, M.E.; Trabelsi, M (2008). Response of common bean lines to inoculation: comparison between the Rhizobium tropici CIAT899 and the native Rhizobium etli $12 \mathrm{a} 3$ and their persistence in Tunisian soils. World J. Microbiol. Biotechnol. 24 (3), 407-417.

43. Yamada Y.; Hoshino, K.; Ishikawa, T. (1997). Taxonomic studies of acetic acid bacteria and allied organisms .11. The phylogeny of acetic acid bacteria based on the partial sequences of $16 \mathrm{~S}$ ribosomal RNA: The elevation of the subgenus Gluconoacetobacter to the generic level. Biosci. Biotechnol. Biochem. 61 (8), 1244-1251.

44. Yamada, Y.; Hoshino, K.; Ishikawa, T. (1998) Gluconacetobacter nom. corrig. (Gluconoacetobacter [sic]). In validation of publication of new names and new combinations previously effectively published outside the IJSB, List no. 64. Int. J. Syst. Bacteriol. 48 (1), 327-328. 